\title{
ПРОБЛЕМНІ ПИТАННЯ ВДОСКОНАЛЕННЯ НАДАННЯ ЗАХИСНИКОМ ПРОФЕСІЙНОЇ ПРАВНИЧОЇ ДОПОМОГИ У КРИМІНАЛЬНОМУ ПРОВАДЖЕННІ
}

Мартовицька О. В.

\begin{abstract}
У науковій статmі здійснено дослідження генезису діі чинного КПК України з 2012 року і дотепер з питань законодавчого забезпечення надання захисником правової допомоги на стадії досудового розслідування, а також гарантій з цих питань, що закріплено в Конституції України. Встановлено наявні розбіжності, неузгодженість та прогалини між Основним Законом, чинним КПК України і Законом України «Про адвокатуру та адвокатську діяльність» з питань забезпечення і реалізації надання захисником професійної правничої допомоги учасникам кримінального судочинства. На підставі результатів дослідження запропоновані конкретні пропозиції і рекомендації з метою удосконалення чинного кримінального процесуального законодавства України.

Ключові слова: досудове розслідування, кримінальний процес, правова допомога, адвокат, захисник, учасники провадження, статус, положення, закон, процесуальні правовідносини, міжнародні акти, захист, суб'єкти, функція, наукова позиція.
\end{abstract}

В научной статье выполнено исследование генезиса действия действующего КПК Украины с 2012 года по настоящее время по вопросам законодательного обеспечения предоставления защитником правовой помощи на стадии досудебного расследования, а также гарантий, которые закреплены в Конституции Украины. Установлены явные расхождения, несогласованность и пробелы между Основным Законом, действующим КПК Украины и Законом Украины «Об адвокатуре и адвокатской деятельности» в вопросах обеспечения и реализации предоставления защитником профессиональной юридической помощи участникам уголовного производства. На основании результатов исследования предоставлены конкретные предложения и рекомендации с целью усовершенствования действующего уголовного прочессуального законодательства Украины.

Ключевые слова: досудебное расследование, уголовный процесс, правовая помощь, адвокат, защитник, участники производства, статус, положение, закон, процессуальные правоотношения, международные акты, защита, субъекты, функция, научная позиция.

The author of the article examined the development of the genesis and current status of use of the Criminal Procedure Code of Ukraine from November 21, 2012 on the existing problematic issues of providing professional legal assistance by the defense counsel, the realization of rights, freedoms and legal interests by participants in criminal proceedings. During the research, the author analyzed the norms of the Constitution of Ukraine, as well as the Law of Ukraine "On Advocacy and Advocate Activity", criminal procedural and other legislation. Also the author of the article pointed out legislative and normative fixation of obligation to provide realization of the constitutional right for legal aid during the pretrial investigation and trial by officials conducting pre-trial investigation, procedural guidance for

Мартовицька О. В., 2019 pre-trial investigation and trial. During the research the author made a comparative analysis of the provisions of the previous Criminal Procedure Code of Ukraine adopted in 1960 and other legislation of that time and the current Criminal Procedure Code of Ukraine adopted in 2012 on the issues discussed in the article. Such research helped to generalize both positive and negative experience of law enforcement activities, which contributed to determine certain proposals and recommendations for improvement current legislation on the issues discussed in the article. In addition, the author identified the existing differences, inconsistencies and gaps between the Basic Law, the current Criminal Procedure Code of Ukraine and the Law of Ukraine "On Advocacy and Advocate Activity" on the provision of professional legal assistance to the participants of criminal procedure and the realization of their rights, freedoms and legal interests in criminal proceedings. Based on the results of the research, analysis of the current legislation of Ukraine, international legal acts, decisions of the European Court of Human Rights, law enforcement practice of pre-trial investigation bodies, prosecutor's offices, judicial instances, specific proposals and recommendations were made. These proposals are aimed to improve the current criminal procedure law in part of the protection by the defense lawyer and officials of the rights, freedoms and legal interests of citizens got included in criminal proceedings. These proposals will be send to the Verkhovna Rada of Ukraine for their legislative fixation.

Key words: pre-trial investigation, criminal procedure, legal assistance, lawyer, defense attorney, participants in the proceedings, status, position, law, procedural legal relationship, international acts, protection, criminal defendants, function, scientific position.

Постановка проблеми та її актуальність. Удосконалення надання захисником правової допомоги на стадії досудового розслідування апробовані національною історією кримінального судочинства, але потребують свого удосконалення, що $є$ актуальним питанням сьогодення для України. Прийняття у 2012 році чинного КПК України з його новелами, зокрема і в частині надання захисником правової допомоги на етапі досудового розслідування, внесло концептуальні зміни в цьому напрямі. Водночас підписання Україною низки міжнародно-правових актів та договорів вимагає подальшого удосконалення надання правової допомоги захисником. Своєю чергою рішення Європейського суду з прав людини (далі - ЄСПЛ), які стали частиною національного законодавства України, мають враховуватись як посадовими особами, так і захисниками у правозастосуванні, що підтверджується значною кількістю звернень нашої країни до цієї міжнародної судової інституції. Забезпечення прав, свобод і законних інтересів особи $\epsilon$ одним із головних чинників визначення демократичної правової держави, що гарантовані Конституцією нашої країни, а згідно зі ст. ст. 55 та 59 така професійна 
правнича допомога має бути забезпечена особам, що потрапили у кримінально-процесуальні правовідносини [1]. Враховуючи актуальність порушених питань, виникає потреба в дослідженні вказаного напряму кримінального процесу.

Аналіз останніх досліджень i публікацій. Порушені в статті питання розглядалися в роботах учених: С.Є. Абламського, О.М. Бандурки, Ю.В. Бауліна, В.П. Бож'єва, В.В. Борисова, Т.В. Варфоломеєвої, Б.Л. Ващука, В.І. Галагана, І.М. Гальперіна, Л.В. Головка, В.Г. Гончаренка, Ю.М. Грошевого, М.І. Гошовського, Є.В. Диденка, М.В. Духовського, В.В. Єрохіна, Ю.Д. Зайцева, Я.П. Зейкана, Д.Ю. Кавуна, С.О. Ковальчука, О.А. Калганова, О.В. Капліної, Г.К. Кожевнікова, А.Ф. Коні, В.В. Лисенка, Л.Д. Кокорева, Н.І. Клименка, О.П. Кучинської, О.О. Кочури, В.Г. Лукашевича, Є.Д. Лук'янчикова, В.Т. Маляренка, М.М. Михеєнка, Т.В. Омельченко, В.Т. Нора, О. Павлюченко, М.А. Погорецького, Т.І. Присяжнюка, В.М. Савицького, М.В. Сенаторова, М.С. Строговича, В.М. Тертишника, Л.Д. Удалової, Т.Г. Фоміної, П.В. Цимбала, В.П. Шибіки, О.Г. Шило, М.Є. Шумило, О.О. Юхна, Ю.П. Яновича та інших. Після прийняття у 2012 році КПК України у кандидатській дисертації ці питання частково досліджувались С.Є. Абламським «Захист прав та законних інтересів потерпілого в кримінальному провадженні» (2014р.); Д.Ю. Кавуном «Кримінальний процесуальний механізм забезпечення прав потерпілого (фізичної особи) на досудовому розслідуванні» (2016р.); А.В. Мельниченко «Забезпечення прав особи на досудовому розслідуванні» (2018 р.). У монографії ці питання вивчалися В.В. Єрохіним (2018 р.); А.В. Сачко в монографії «Забезпечення верховенства права при застосуванні особливих порядків та режимів кримінального провадження» (2019р.) та в докторській дисертації з цієї тематики, а також ці питання досліджувались фрагментарно і іншими вченими. Водночас за період дії чинного КПК України до нього, станом на кінець 2019 року, було внесено більш 580 змін, доповнень та поправок, положення яких ще не знайшли свого відображення у дослідженнях учених.

Метою цієї статті $\epsilon$ необхідність подальшого дослідження проблемних питань та шляхів їх удосконалення щодо надання професійної правничої допомоги у кримінальному провадженні, що викликано недосконалістю, а в окремих випадках і відсутністю синхронізації між чинним кримінальним процесуальним законодавством України та окремими законами та практикою їх застосування з метою дослідження цих питань та напрацювання пропозицій та рекомендацій із внесення відповідних доповнень та змін до КПК України.

Виклад основного матеріалу. Натепер завданням законодавця $\epsilon$ наповнення реальним змістом забезпечення права на професійну правничу допомогу у всіх сферах суспільного життя і насамперед у сфері кримінального судочинства. Саме новели чинного КПК України дещо знизили дискусійність питання про те, хто ж має бути захисником у кримінальному процесі. Однак тільки наявності закону про захист не досить, потрібний правовий механізм його реалізації, щоб людина могла скористатися правовою допомогою тоді, коли вона їй найбільше необхідна. Як слушно зазначили О.Д. Святоцький та В.В. Медведчук, головне не в проголошенні самого права, а у його змісті та правовому механізмі забезпечення та здійснення [2, с. 75-76], що ми підтри- муємо. Із приводу «професійності» $\mathbf{i}$ «фаховості» у науці точилася активна дискусія стосовно якісних та інших показників, яким має відповідати захисник. При цьому, як зазначав І.Ю. Головацький, поняття «фахівець у галузі права» не має свого офіційного визначення, не може бути співвіднесено із поняттям «вища або повна вища юридична освіта» відповідно до освітньо-кваліфікаційних рівнів, визначених Законом України «Про вищу освіту». Крім того, на його думку, у цьому разі на такого захисника не поширюватимуться Правила адвокатської етики [3, с. 141]. Подібну думку висловлював Я.П. Зейкан, якийвказав нанедоцільністьдопускудоучастіусправі осіб, які не мають адвокатського посвідчення [4, с. 8], що ми підтримуємо. Як свідчить дослідження, чинний КПК України містить новий підхід до вирішення таких питань та вказує на професійність і наявність належної компетенції захисника-адвоката у сфері надання правничої допомоги, що частково узгоджено із положенням Закону України «Про адвокатуру та адвокатську діяльність» [5], зокрема щодо вимог до осіб, які бажають стати захисником-адвокатом (ст.ст. 6 та 7), необхідності складання кваліфікаційного іспиту (ст.ст. 8 та 9), проходження стажування та прийняття присяги (ст.ст. 10, 11,12 ), обов'язків захисника-адвоката (ст. 21), а також можливості тимчасового зупинення та припинення права на зайняття адвокатською діяльністю. Справді, натепер у цілому інститут правничої допомоги відповідає сучасним вимогам. Зазначимо, що за чинним законодавством значно ускладнено процедуру отримання посвідчення адвоката. Відповідно до ст. 6 Закону України «Про адвокатуру та адвокатську діяльність» захисником-адвокатом може бути фізична особа, яка має повну вищу юридичну освіту, володіє державною мовою, має стаж роботи в галузі права не менше двох років, склала кваліфікаційний іспит, пройшла стажування (крім випадків, установлених цим Законом), склала присягу адвоката України, отримала свідоцтво про право на зайняття адвокатською діяльністю. При цьому стаж юридичної роботи зараховується лише після отримання диплома про вищу юридичну освіту (диплома спеціаліста й більш високого рівня). Однак, незважаючи на позитивність і прогресивність його положень, окремі питання все ж таки потребують повного і комплексного дослідження. Зокрема, необхідно звернути увагу на положення ст. 7 Закону України «Про адвокатуру та адвокатську діяльність», де встановлено, що вимоги щодо несумісності з діяльністю адвоката не поширюються на депутатів Верховної Ради Автономної Республіки Крим, депутатів місцевих рад (крім тих, які здійснюють свої повноваження у відповідній раді на постійній основі). На нашу думку, не слід допускати до виконання функції захисту та надавати статус захисника-адвоката тих фахівців у галузі права, які $\epsilon$ представниками будь-якої гілки влади, включаючи законодавчу (депутатів будь-яких представницьких органів - від Верховної Ради до органів місцевого самоврядування), виконавчої, включаючи представників правоохоронних органів, та судової (включаючи осіб, які занесені до списку присяжних). Як справедливо зазначили Г.З. Алієв, О.О. Самодіна та А.В. Самодін, у розрізі європейських правовихстандартівреалізаціяправісвободлюдиниусфері кримінальних процесуальних відносин, а також нормативно-правового забезпечення діяльності інституцій адвокатури особливої уваги заслуговують окремі правові аспекти забезпечення конституційних положень права 
підозрюваного, обвинуваченого на захист у кримінальному провадженні [6, с. 91]. Таку позицію слід підтримати, але частково. На нашу думку, реалізація конституційних положень з цих питань передбачає надання професійної правничої допомоги кожній особі. У зв'язку з цим слід підтримати думку В.М. Царьова, який відзначив, що найближчими до істини $\epsilon$ ті вчені, які вважають захисника самостійним учасником кримінального провадження, а не визначають його процесуальне положення через відношення до обвинуваченого. Адвокат здійснює захист прав законними засобами і на нього покладається навіть більше обов'язків, ніж на обвинуваченого. Крім цього, на нашу думку, на ньому лежить велика моральна відповідальність, яка не має підкорятись, наприклад політичній, партійній, релігійній чи іншій належності. Наведені наукові позиції свідчать про те, що питання, пов'язані з участю захисника-адвоката у кримінальному провадженні, розглядаються в основному через призму відносин із підозрюваним і обвинуваченим. Справді, якщо розглядати це питання тільки у такий спосіб відносин захисника-адвоката із підозрюваним і обвинуваченим, то, на нашу думку, втрачає своє значення змагальність сторін та вільний вибір, зокрема у поданні ними до суду своїх доказів і доведення перед судом їх переконливості та правової позиції. У зв'язку з цим ми підтримуємо думку Л.Д. Удалової, яка вважає, що прогресивним $\epsilon$ закріплення додаткових гарантій реалізації принципу змагальності сторін, у тому числі під час досудового розслідування. Зокрема, сторонам гарантуються рівні права щодо збирання та подання до суду клопотань, скарг, речей, документів, доказів, а також реалізації інших процесуальних прав і свобод (ст. 22 КПК України) [7, с. 8-9]. Однак нині спостерігається непропорційність щодо реалізації захисником права на надання правової допомоги учасникам кримінального провадження. Про незалежність, вільний вибір захисника, рівність осіб на доступ до правової допомоги, своєчасну інформативність про право на отримання і реалізацію правової допомоги, компетентність правової допомоги також зазначено й у міжнародних правових документах. Крім цього, взагалі відсутній процесуальний і чіткий механізм щодо збирання захисником доказів, що потребує удосконалення на законодавчому рівні. На нашу думку, також потребує унормування положення ч. 2 ст. 45 чинного КПК України про те, що захисником не може бути адвокат, відомості про якого не внесено до Єдиного реєстру адвокатів України або стосовно якого у Єдиному реєстрі адвокатів України містяться відомості про зупинення або припинення права на зайняття адвокатською діяльністю. При цьому ч. 2 ст. 50 КПК України прямо визначає недопустимість встановлення будь-яких додаткових вимог, крім пред'явлення захисником документа, що посвідчує його особу, або умов для підтвердження повноважень захисника чи для його залучення до участі у кримінальному провадженні. Положення ч. 2 ст. 45 КПК України, хоча і викладено у формі заборони, разом із тим не передбачає підстав та обов' язку перевірки дійсності свідоцтва про право на зайняття адвокатською діяльністю. У зв'язку із цим доцільно доповнити ст. 45 КПК України додатковою частиною 3 та викласти у такій редакції: «у разі виникнення обґрунтованого сумніву щодо невнесення відомостей про адвоката до Єдиного реєстру адвокатів України або наявності у ньому відомостей про тимчасове зупинення чи припинення права особи на зайняття адвокатською діяльністю слідчий, прокурор, слідчий суддя або суд мають право надіслати запит до Ради адвокатів України або відповідної ради адвокатів регіонів, про що повідомляється адвокат, стосовно якого такий запит направлено. Направлення запиту не $\epsilon$ підставою для позбавлення адвоката права здійснювати захист у кримінальному провадженні». Крім цього, доцільно ст. 45 КПК України доповнити додатковою частиною 4, яку викласти у такій редакції: «У разі відсутності в Єдиному реєстрі адвокатів України відомостей про конкретного адвоката за зверненням (письмовим запитом) органів досудового розслідування, прокурора, слідчого судді або суду щодо підтвердження дійсності свідоцтва про право особи на зайняття адвокатською діяльністю і відсутністю відповідних відомостей у Єдиному реєстрі адвокатів України щодо допуску до участі адвоката у кримінальному провадженні Рада адвокатів України і відповідні радиадвокатіврегіонівнадаютьписьмовувідповідьтавитяг з Єдиного реєстру адвокатів України негайно». Ще одним зі спірних та неузгоджених положень щодо правової підстави початку надання захисником професійної правничої допомоги є договір із захисником. Зокрема, у чинному КПК України не встановлено форму такого договору: чи вона має бути письмовою, чи то усною. Лише загальні положення щодо права укладання такого договору містяться у ст. 51 КПК України. Більш детально це питання відображене лише у Законі України «Про адвокатуру та адвокатську діяльність», де у ст. 27 встановлено, що договір про надання правової допомоги укладається у письмовій формі, але як виняток договір про надання правової допомоги може вчинятися усно у разі, якщо клі$\epsilon$ нт невідкладно потребує надання правової допомоги, а укладення письмового договору за конкретних обставин $\epsilon$ неможливим, 3 подальшим укладенням договору у письмовій формі протягом трьох днів, а якщо для цього $\epsilon$ об'єктивні перешкоди - у найближчий можливий строк. У зв'язку з цим, на нашу думку, для уникнення протиріч між КПК України і вказаним Законом з цих питань доцільно ч. 1 ст. 51 КПК України доповнити положенням та викласти його у такій редакції: «Договір із захисником про правову допомогу у письмовій формі має бути укладений протягом трьох днів, а якщо для цього $\epsilon$ об'єктивні перешкоди - у найближчий можливий строк». Крім того, доцільнодоповнитидодатковоючастиною2ст. 51 КПК України, яку викласти у такій редакції: «Договір із захисником може вчинятися усно за умови, якщо затримана особа чи особа, яка тримається під вартою, висловила вимогу щодо особистого запрошення захисника і така правова допомога їй потрібна негайно, а конкретні обставини унеможливлюють укладення письмового договору. Про факт укладення усного договору про надання професійної правничої допомоги захисник негайно письмово повідомляє слідчого, прокурора, слідчого суддю або суд, який здійснює кримінальне провадження». У разі усного укладення договору на правову допомогу адвокату слід враховувати й положення ст. 28 Закону України «Про адвокатуру та адвокатську діяльність» щодо підстав для відмови в укладенні договору про надання правової допомоги, які не зовсім узгоджуються із положеннями ч. 4 ст. 47 КПК України. Зокрема, у ч. 1 ст. 28 Закону України «Про адвокатуру та адвокатську діяльність» передбачено сім підстав щодо відмови виконання захисником своїх обов'язків, водночас у ч. 4 ст. 47 КПК України передбачено лише 
чотири такі підстави. Таке протиріччя доцільно усунути за рахунок внесення відповідних доповнень і уточнень до чинного КПК України.

Слід звернути увагу, що у чинному КПК України передбачено положення щодо присутності захисника під час провадження слідчих (розшукових) дій. Проте, враховуючи це положення, чи означає це, що в цьому разі присутність обмежується тільки його пасивною роллю. Однак у кримінальному провадженні захисник не лише присутній під час проведення слідчим різних слідчих (розшукових) дій, але й бере активну участь у них: ставить питання з дозволу слідчого, заявляє клопотання щодо порядку проведення слідчої (розшукової) дії, про його доповнення, знайомиться із протоколом. Таким чином, захисник активно бере участь у слідчих (розшукових) діях і всіма законними засобами й способами прагне з'ясувати обставини, які виправдовують підозрюваного або пом'якшують його відповідальність. Питання виникає з того приводу, що негласні слідчі (розшукові) дії проводяться зазвичай таємно й участь у них захисника проблематична. Як відомо, одним з ефективних засобів, який дає змогу захиснику виконувати свої професійні обов'язки у кримінальному провадженні, $\epsilon$ подання клопотань. 3 їхнью допомогою він може спонукати слідчого до провадження тих чи інших слідчих (розшукових) дій, призначення експертиз, перевірки певних доказів і версій, доводити до відома слідчого, прокурора свою думку про доведеність оголошеної підозри, обґрунтованість кваліфікації, доцільність прийняття конкретних процесуальних рішень. Клопотання захисника, як зазначає І.М. Одинцова, - це його письмове або усне офіційне звернення до слідчого, прокурора, керівника слідчого підрозділу, слідчого судді або працівників оперативних підрозділів, які вповноважені за дорученням слідчого здійснювати кримінальну процесуальну чи оперативно-розшукову діяльність, про вчинення цими особами дій, що входять до їхньої компетенції, і спрямоване на захист прав та законних інтересів підозрюваного, обвинуваченого. Перед тим як заявити клопотання у захисника має сформуватися тверда переконаність, що воно не потягне за собою погіршення становища підзахисного. Захисник також має з'ясувати його думку про необхідність подання клопотання, узгодити з ним зміст, повідомляти про те, як можуть бути використані в інтересах захисту дані, отримані в результаті клопотання, які рішення у справі можуть бути прийняті за клопотанням. У клопотаннях захисника можуть ставитися питання про доцільність вилучення певних документів, про допит нових свідків, проведення впізнання, освідування та інших слідчих (розшукових) дій, призначення експертиз, про скасування або зміну запобіжного заходу, про закриття провадження тощо [8, с. 209], що ми підтримуємо.

Висновки. Здійснюючи дослідження прав захисника у кримінальному провадженні, можна зазначити, що у КПК України права захисника викладено не досить коректно та дещо звужено. Зокрема, у п. 4 ст. 46 КПК України встановлено, що захисник користується процесуальними правами підозрюваного, обвинуваченого, захист якого він здійснює, крім процесуальних прав, реалізація яких здійснюється безпосередньо підозрюваним, обвинуваченим і не може бути доручена захис- нику. Водночас у Законі України «Про адвокатуру і адвокатську діяльність» права саме адвоката ширші. Тут він має право збирати відомості про факти, які можуть бути використані як докази, зокрема: запитувати й одержувати документи або їх копії від підприємств, установ, організацій, об'єднань, а від громадян - за їх згодою; ознайомлюватися на підприємствах, в установах, організаціях із необхідними документами і матеріалами, крім тих, таємниця яких охороняється законом; отримувати письмові висновки фахівців із питань, що потребують спеціальних знань. 3 метою повної та ефективної реалізації покладених на захисника обов' язків доцільно права захисника визначити у положеннях КПК України окремо. При цьому, враховуючи особливості кримінальної процесуальної діяльності, права захисника у кримінальному провадженні мають бути визначені більш вагомо, ніж права адвоката, визначені в Законі України «Про адвокатуру і адвокатську діяльність». Доцільно законодавчо закріпити захиснику право отримувати різні документи, зокрема довідки, характеристики, копії договорів, накладних, а також отримувати предмети від підозрюваного, обвинуваченого, засудженого, виправданого, їхніх родичів та інших осіб. При цьому також доцільно передбачити додаткові положення, що на захисника не поширюються владні повноваження на вилучення документів чи інших об'єктів, а документи або предмети, зібрані та пред'явлені захисником, ще не $\epsilon$ доказом, тому вони мають бути оцінені щодо належності їх до кримінального провадження, зокрема й щодо допустимості та достовірності.

\section{Література}

1. Конституція України від 28.06.1996 р. Відомості Верховної Ради України. 1996. №. 30. Ст. 141.

2. Святоцький О.Д., Медведчук В.В. Адвокатура: історія і сучасність. Київ : Ін. Юре. 1997. 320 с.

3. Головацький І.Ю. Діяльність адвоката-захисника у кримінальному процесі : навчальний посібник. Київ : Атіка. 2003. 352 c.

4. Зейкан Я.П. Захист у кримінальній справі : науково-практичний посібник. Київ : Вища школа. 2002. 271 с.

5. Про адвокатуру та адвокатську діяльність : Закон України від 05.07.2012 № 5076-VI. Відомості Верховної Ради (ВBP). 2013. № 27. Ст. 282.

6. Алієв Г.3., Самодіна О.О., Самодін А.В. Окремі аспекти залучення захисника у кримінальне провадження за новим кримінальним процесуальним законодавством України. Юридична наука. 2013. № 3. С. 91-99.

7. Удалова Л. Деякі проблемні питання правозастосування кримінального процесуального законодавства. Збірник матеріалів міжвузівської наукової конференції «Актуальні питання кримінального процесуального законодавства України» (Київ, 26 квітня 2013 року). Національна академія прокуратури України. Київ : Алерта. 2013. С. 8-12.

8. Одинцова І.М. Право на захист на досудовому розслідуванні за новим КПК України. Право і суспільство. 2013. № 2. С. 207-211.

Мартовицька О. В., кандидат юридичних наук, дочент кафедри кримінального прочесу та організації досудового слідства Харківського національного університету внутрішніх справ 